\title{
The effects of China's grassland contract policy on Mongolian herders' attitudes towards grassland management in northeastern Inner Mongolia
}

\author{
Thomas J. Conte ${ }^{1}$ \\ Rutgers University, USA
}

\begin{abstract}
China's Inner Mongolia Autonomous Region is experiencing high levels of grassland degradation partially as a result of government policies to sedentarize nomadic pastoralists and privatize collective grasslands. Previous research suggests that these policies have reduced Mongolian pastoralists' ability to effectively manage grasslands and cope with negative climatic events. Herders in New Barag Right Banner $(\mathrm{n}=50)$ representing both sedentary and mobile livestock management strategies were asked to respond to a scaled survey regarding their attitudes towards the effectiveness of their current grassland management strategies and their perceptions regarding the future of pastoralism in Inner Mongolia. Inter-rater reliability and MannWhitney U Tests were utilized to compare the attitudes towards grassland management and the future viability of livestock production and to test whether or not sedentary and mobile herders share the same attitudes towards these facets of their pastoral way of life. There is both high intra and inter-group agreement on the survey variables across settlement categories, indicating that sedentary and mobile herders share the same attitudinal orientations regardless of their settlement patterns. The implications of these results for future grassland policy and sustainable livestock production are also discussed.
\end{abstract}

Keywords: pastoralism, China, Inner Mongolia, grassland policy, privatization, marketization

\section{Résumé}

Mongolie intérieure de la Chine connaît des niveaux élevés de dégradation des prairies, en partie à cause des politiques gouvernementales qui essaient de sédentariser éleveurs nomades et de privatiser les prairies collectives. Des recherches antérieures suggèrent que ces politiques ont réduit la capacité des pasteurs mongols à gérer efficacement les prairies et faire face aux événements climatiques négatifs. On a demandé aux éleveurs à New Barag Right Bannière $(\mathrm{n}=50)$ de répondre à un sondage à l'échelle sur leurs attitudes à l'égard de l'efficacité de leurs stratégies de gestion des prairies actuelle et leurs perceptions quant à l'avenir du pastoralisme en Mongolie intérieure. Ils représentaient les deux stratégies de gestion du bétail sédentaires et mobiles. Le coefficient d'objectivité et de Mann-Whitney U tests ont été utilisés pour comparer leurs attitudes envers la gestion des prairies et de la viabilité future de la production animale, et de tester si oui ou non les éleveurs sédentaires et mobiles partagent les mêmes attitudes à l'égard de ces aspects de leur mode de vie pastoral . Il ya accord sur les variables de l'enquête dans toutes les catégories d'établissement, entre les groupes et entre les groupes, ce qui indique que les éleveurs sédentaires et mobiles partagent les mêmes orientations attitudes indépendamment de leurs modes d'établissement. Les implications de ces résultats pour la future politique de prairies et de la production animale durable sont examinés.

Mots-clés: pastoralisme, la Chine, la Mongolie intérieure, la politique de prairies, de la privatisation, marchandisation

\footnotetext{
${ }^{1}$ Thomas J. Conte, doctoral student, Department of Anthropology, Rutgers University, New Jersey 08901, USA. Email: thomasconte "at" gmail.com. This research was supported by funding from the Ryoichi Sasakawa Young Leaders Fellowship Fund Program. I would like to thank Dr. Liu Bingwan and Li Jianshu of Northeast Forestry University in Harbin, China for their help with field surveys and interviews and the pastoral community of New Barag Right Banner for their hospitality and participation. I also would like to thank Dr. Bryan Tilt, Dr. Shane Macfarlan, and Justin Holcomb for their guidance during the data analysis process.
} 


\section{Resumen}

En China, la Región Autónoma de Mongolia Interior está experimentando altos niveles de degradación de las praderas como resultado de políticas gubernamentales destinadas a convertir en sedentarias poblaciones nómadas dedicadas al pastoreo y a privatizar praderas de uso colectivo. Investigaciones previas sugieren que estas políticas han reducido la habilidad de los pastores mongoles para gestionar las praderas y superar eventos climáticos negativos. Un total de cincuenta pastores de la franja derecha de New Barag, con estrategias de ganadería tanto nómada como sedentaria, respondieron a un cuestionario tipo escala sobre sus actitudes respecto a la efectividad de sus actuales estrategias de gestión de las praderas y sobre sus percepciones respecto al futuro del pastoreo en Mongolia Interior. A fin de comparar las actitudes respecto a la gestión de las praderas y la viabilidad futura de la producción ganadera, así como de comprobar hasta qué punto pastores sedentarios y nómadas comparten las mismas actitudes hacia estas facetas de su vida como pastores, se usaron los test de fiabilidad entre evaluadores y de Mann-Whitney U. Se observa un alto nivel de acuerdo tanto en cada grupo como entre un grupo y otro en las respuestas a las variables, indicando que los pastores nómadas y los sedentarios comparten las mismas orientaciones en su actitud, independientemente de sus patrones de asentamiento. Se discuten igualmente las implicaciones de estos resultados para futuras políticas sobre las praderas y la producción ganadera.

Palabras clave: pastoreo, China, Mongolia Interior, políticas de las praderas, privatización, comercialización

\section{Introduction}

The grasslands of northern China's Inner Mongolia Autonomous Region are currently one of the epicenters of global desertification, even as the Chinese government is attempting to create policies to curb degradation of its grasslands. Previous research suggests that one major contributing factor to grassland degradation in Inner Mongolia is China's Grassland Contracting Policy and the Household Responsibility System, which have encouraged the privatization of livestock production and the integration of the Inner Mongolian pastoral economy with global markets for livestock products (Ho 1996; Humphrey and Sneath 1996a; Taylor 2012). This is because these policies have been shown to have eroded the ecologically adaptive nomadic grazing and common-pool resource management strategies that allowed herders to collectively manage grasslands in the past (Li and Huntsinger 2011; Williams 2002).

This study utilized a political ecology approach to analyze the effects of the privatization of grassland on a small population of Mongolian pastoralists in northeastern Inner Mongolia's New Barag Right Banner. Previous research in political ecology suggests that state-level land management policy decisions often do not align with the traditional management strategies and values of smallholder and indigenous populations (e.g. Dove 1996; 1986; Jiang 2004), and often lead to economically and ecologically unsustainable natural resource management. Because the regional government of Inner Mongolia has instituted policies to sedentarize formerly nomadic herders and to privatize grasslands that were formerly common property, local pastoralists are divided in their land management responses to the new privatized system such that some attempt to retain seasonal movement, while others elect to remain fully sedentary. Thus, local pastoralists are attempting to respond to state-level policy decisions by integrating traditional land management practices with the land management goals of new grazing policies. The author measured and compared sedentary and mobile herders' attitudes towards current grassland management and the future of pastoralism in three Inner Mongolian casestudy villages, in light of the privatization of grassland and the elimination of nomadic grazing in the region. The results indicate that the study population believes that seasonal mobility is key to maintaining healthy grasslands, but given the state of Chinese grassland policy, pastoralists share the same attitudinal dispositions towards state policy regardless of their settlement strategy.

\section{Background: current land management in Inner Mongolia and its consequences}

Northern and western China contains some of the world's most extensive grassland resources. Nearly half of Chinese territory is categorized as temperate, desert, and alpine grasslands which are utilized by pastoralists to sustain herds of horses, sheep, goats, camels, and cattle. Northern China's Inner Mongolia Autonomous Region (IMAR) contains nearly 20 percent of China's total grassland resources and has been 
managed by Mongolian pastoralists and their ethnic predecessors for at least three millennia (Deng et al. 2009; Lattimore 1941).

Since the latter half of the $20^{\text {th }}$ century, however, Inner Mongolia has been one of the focal points of desertification and grassland degradation in China. The effects of this ecological degradation include an overall deterioration of grassland productivity, decreased plant species biodiversity, and the expansion of desert conditions into pastoral and agricultural areas (Williams 2002). At present, it is estimated that over 90 percent of Chinese grasslands are degraded and desert conditions expand over 10,000 km² annually in China's dryland interior (Nelson 2006). Previous research suggests that grassland degradation is a result of the expansion of agriculture into grassland regions ecologically unsuitable for farming, and the implementation of land tenure and grassland management policies that have led to the collapse of nomadic grazing and the common pool resource management strategies that were common in IMAR prior to the 1950s (Humphrey and Sneath 1996a; Humphrey and Sneath 1999; Jiang 2004; Taylor 2006). In particular, previous studies highlight the role that the Household Responsibility System and Grassland Contracting Policy initiated by the reform government of Deng Xiaoping have had in the collapse of the nomadic grazing strategies of Mongolian herders and the settlement patterns that allowed their practice (Ho 1996; Li and Huntsinger 2011). The Household Responsibility System aimed to decollectivize agricultural land by allocating state owned farmland to individual families, and by giving families the autonomy to grow crops according to market demand rather than state-mandated production quotas. This policy was largely successful in integrating China's agricultural sector with international and domestic markets for agricultural products and improving rural household incomes (Tilt 2008).

In response to the successes of the Household Responsibility System, from the early 1980s to the mid1990s, the Inner Mongolian regional government sought to implement policies designed to curb grassland degradation and increase economic growth by integrating the pastoral economy with growing international and domestic markets for livestock products (Ho 1996; Ma 2003). The Grassland Contracting Policy privatized formerly collective grassland by contracting pastures to individual herding families in the same way that agricultural land was divided among farmers under the Household Responsibility System (Rozelle et al. 2005; Tilt 2008). Through this policy, the Inner Mongolian government hoped to mitigate the 'tragedy of the commons' that they felt would cause degradation on common grasslands, as well as attain the same levels of economic growth and rural income increases in the pastoral economy as had been achieved in the agricultural sector following the privatization of farmland (Fratkin 1997; Hardin 1968; Zukosky 2008). Key to the implementation of these new rural policies was the encouragement of pastoralists to cease seasonal nomadic migration, follow set livestock carrying capacities for grassland, and fence their family pasture allocations to prevent other herders from accessing them (Banks and Doman 2001).

Rather than improving ecological and economic conditions, the privatization of grassland has been suggested to be a key contributing factor in the progressive deterioration of Inner Mongolian grasslands, because it has led to the collapse of the traditional mobile grazing practices that allowed Mongolian herders to flexibly manage the variable climatic and topographic conditions of their grasslands (Fernandez-Gimenez and Le Febre 2006; Jiang 2004). Before the privatization of grasslands and the sedentarization of herders, Inner Mongolian pastoralists practiced a nomadic strategy centered on seasonal migrations that allowed grasslands long periods of regeneration after they had been grazed. In addition, through seasonal migration, herders were able to draw upon Mongolian traditional ecological knowledge to make decisions on where to move their livestock based on their livestocks' plant species preferences and seasonal dietary and water needs (Fernandez-Gimenez 2000). Therefore, the nomadic system of livestock management contributed to the sustainable management of Inner Mongolian grasslands because it allowed herders to efficiently utilize grassland resources and more widely distribute grazing pressure across available pastures.

Nomadic migration also enabled Mongolian herders to cope with the variable annual climatic conditions and Inner Asian grasslands' susceptibility to negative climatic events (Sheehy 1993). The regional climate experiences periodic severe weather conditions known as $d z u d$, which are a major threat to both livestock health and the economic livelihoods of pastoralists. Dzud can come in the form of droughts (black disaster), severe snowstorms (white disaster), and other combinations of inclement weather and precipitation conditions (Begzsuren et al. 2004). Some of the most dangerous conditions occur when a severe snowstorm is 
followed by a rapid rise and decrease in temperature that causes a thick layer of ice to form over snow. Livestock are unable to reach the forage under the ice, and thus, if not provided with supplementary fodder, they can starve during the winter or the following spring. It is estimated that $d z u d$ occurring in the Republic of Mongolia from 1999-2010 killed nearly 21 million head of livestock and contributed to the complete loss of many pastoral families' herds (Sawyer 2010; UNDP 2010).

Traditionally, Mongolian herders in Inner Mongolia and in the sovereign nation to the north and west, the Republic of Mongolia, responded to dzud through the practice of additional seasonal pastoral movements known as otor, involving short distance migrations or long distance movements into neighboring districts and provinces less affected by the dzud (Humphrey and Sneath 1996a). Thus, this mobile system enabled herders to better respond to the variable grassland conditions that exist on much of the Mongolian Plateau through a highly flexible grassland management system. In addition, pastoralists depended on traditional ecological knowledge and also cooperation with other herders to determine which areas to practice otor, when to move, and whether the risks of movement outweighed the potential benefits (Ericksen, personal communication, March 21, 2013; see also Ericksen 2013; Fernandez-Giminez and Diaz 1999; McCabe 2004).

Following the allocation of pastures to individual households in the 1980s-1990s and the widespread enclosure of grasslands with fences, Inner Mongolian herders have been unable to conduct either flexible seasonal migrations or emergency otor. Since Inner Mongolian herders are no longer able to practice the degree of seasonal mobility that was common prior to the privatization of grassland, constant grazing pressure is placed on small family pasture allocations rather than being spread over multiple seasonal pastures. Under the present privatized system, if they wish to conduct an otor or seasonal migration, pastoralists must now acquire the use of additional seasonal pastures by renting land from other families. Therefore, whereas in the past, seasonal migrations were based on traditional ecological knowledge and the seasonal needs of livestock species, movements are now made based almost solely on the availability of pastures for rent and whether they are able to pay monetary compensation. Herders that are not able to rent additional pastures must rely on securing external sources of supplementary fodder to meet the nutritional needs of their livestock and to cope with negative climatic events (Williams 1996). In addition, Williams (2002) found that land tenure insecurity played a significant role in shaping herders' negative attitudes regarding their ability to maintain long-term use of their family pasture and their unwillingness to engage in sustainable grassland management practices, because they might not be able to manage the same land in the future.

Based on the findings of previous studies, the author hypothesized that there would be an observable difference in attitudes towards grassland management and the future of pastoralism in NBR between herders representing the current sedentary livestock production system, and those with memories of the traditional nomadic strategy ( $\mathrm{Li}$ and Huntsinger 2011; Williams 2002). The New Barag Right Banner (NBR, hereafter) of Northeastern Inner Mongolia provided an ideal setting to measure pastoralists' attitudes towards grassland management because it did not adopt privatization policies until 1996, nearly two decades after most the other regions of Inner Mongolia. Thus, many pastoralists in the region have had experience in both the traditional nomadic system of livestock production and the current sedentary system. Moreover, many herders in NBR choose to continue practicing seasonal mobility by conducting migrations to pastures rented from other families. Presumably, herders who have been able to retain some seasonal mobility would have a more positive attitude towards grassland management and the future of pastoralism than those who are sedentary, because the former are able to maintain a grazing strategy more similar to the traditional nomadic system than sedentary herders. The aim of this study was to understand the effects of changing pastoral policies on the attitudes of a small group of herders representing the transition of pastoral production from a nomadic to a sedentary system.

Measuring pastoralists' perceptions of current Chinese grassland management policies and the future viability of pastoralism in northeastern Inner Mongolia is important because it helps emphasize how smallscale resource users respond to state-mandated natural resource policy changes. In the case of NBR, it is clear that pastoral families are divided in their response to policy changes such that some have accepted full sedentarization while others are trying to adapt their livestock management strategies in a way that allows them to retain some degree of seasonal mobility. Previous research ( $\mathrm{Li}$ and Huntsinger 2011; Jiang 2004; Williams 2002) suggests that sedentarization policies are contributing not only to land degradation in Inner 
Mongolia, but also to pastoralists' negative attitudes towards the future economic viability of animal husbandry in the region. However, few studies to date have explored how herders' divided land management responses to sedentarization policies may affect their attitudes towards land management and their perceptions of their ability to make a viable living from pastoralism in the future.

\section{New Barag Right Banner, Inner Mongolia Autonomous Region}

This study explored herder perceptions in three case study villages: Dashimo (pop = 835), Hulun No'er (pop $=255$ ), and Ehe No'er (pop $=458$ ) of the New Barag Right Banner of Northeast Inner Mongolia's Hulunbuir League. The area represents $23,000 \mathrm{~km}^{2}$ of Inner Mongolia's temperate grassland and shares international borders with the Russian Federation to the north and the Republic of Mongolia to the west and south (Figure 1). The banner is dominated by short-grass steppe that receives between 200-300mm of annual precipitation (Daly and Hannaway 2005; Hu et al 1992). NBR is a unique place to study changes in grassland management and pastoralist attitudes because, unlike other areas of Inner Mongolia and Hulunbuir League as a whole, NBR's grasslands were not affected by the encroachment of agriculture into traditionally pastoral areas during the $19^{\text {th }}$ and $20^{\text {th }}$ centuries (Figure 2).

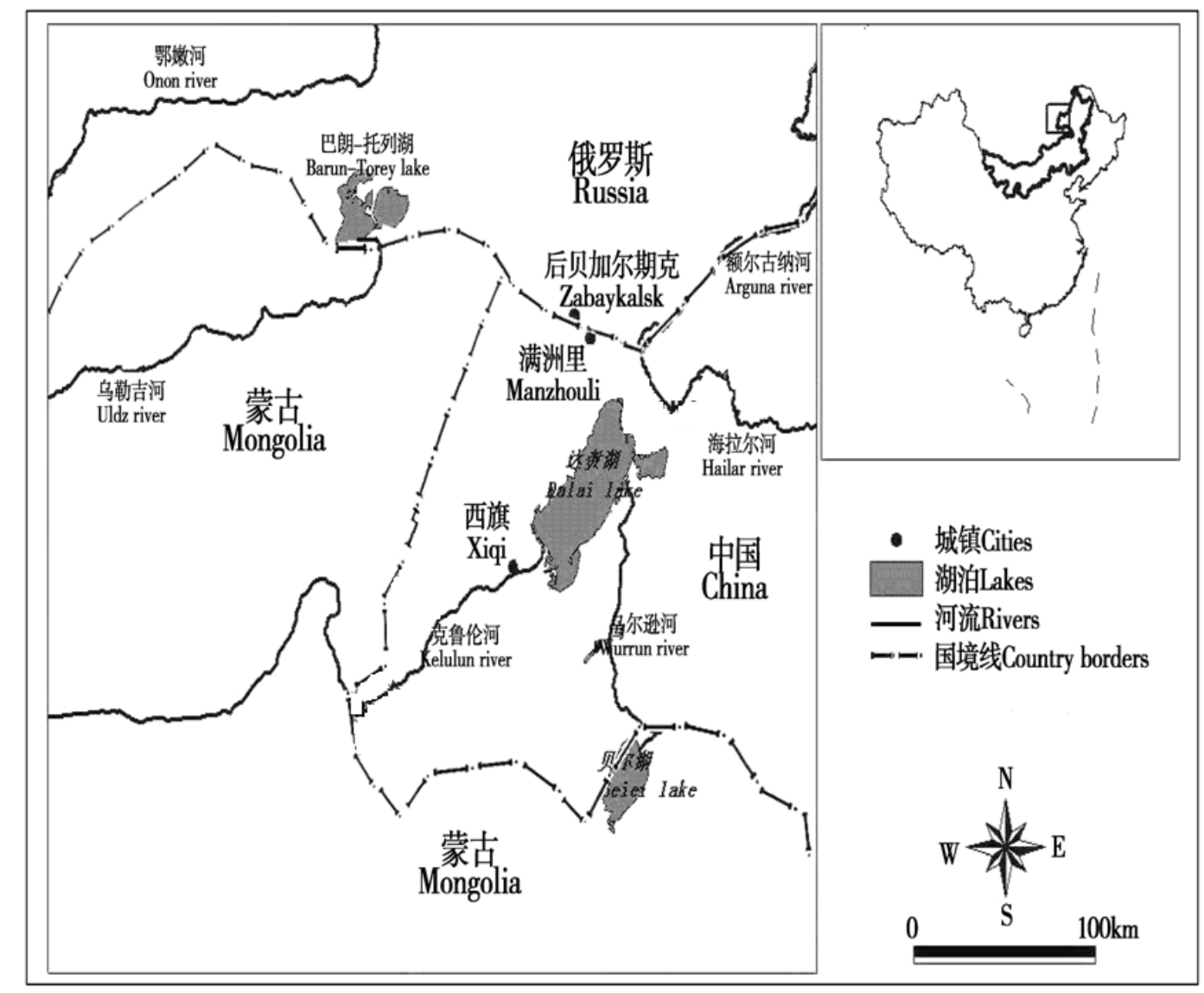

Figure 1: Map of the study area in Inner Mongolia, China. Source: Liu n.d.

The main regional economic activities include pastoralism as well as recently established copper, coal, and molybdenum mining industries. Village centers also include services such as restaurants, grocery stores, and mechanics shops that serve village residents and the surrounding pastoral population. The average annual per capita income for the pastoral population of the three study villages in 2011 was 8,369 CNY ( US\$1,300), which is roughly equal to the 2012 national average rural income for China (Holmes 2012). The Banner's 
population is dominated by ethnic Barga Mongols who have traditionally populated the western areas of Hulunbuir League and the extreme eastern portion of the Republic of Mongolia. The Barga are a subgroup of the Buryat Mongols that live in northeastern Mongolia and in the Trans-Baikal region of Siberia, and speak a Buryat-Mongol dialect (Humphrey and Sneath 1996a, 1996b). However, both the village and pastoral populations include some Han Chinese whose families migrated into the region from other provinces following periods of famine and economic strife in the 1950s and 1960s (Pasternak and Salaff 1993). Before the 1990s, like other regions of Inner Mongolia, NBR pastoralists practiced mobile pastoralism characterized by seasonal nomadic migrations and collective management of grasslands. Herders typically made between four and ten annual pastoral movements, but during years of poor precipitation, harsh winters, or drought, they might have made as many as thirty movements and emergency otor.

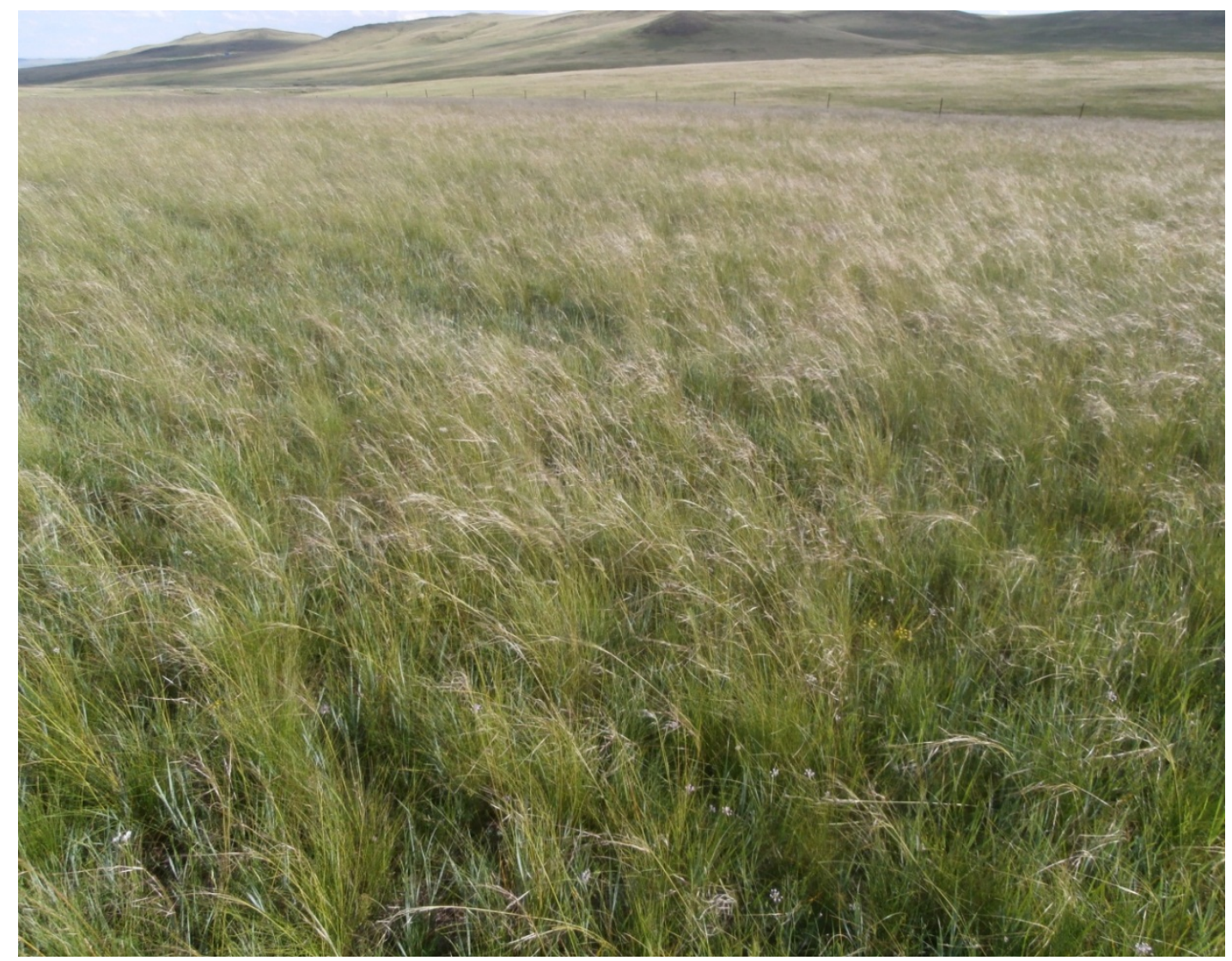

Figure 2: Fenced pastures in New Barag Right Banner. The plant species associations are dominated by Stipa baicalensis, a species of needle grass that both local officials and pastoralists assert is harmful to livestock and an indicator of overgrazing. Source: author.

Similar to other pastoral regions of Inner Asia, during the Qing Dynasty (1644 - 1912), pastoral production in NBR was regulated by local elites and feudal princes as well as by Buddhist monasteries that held economic and political authority over pastoral regions. These ruling institutions collected taxes and tribute from pastoralists for the imperial government and regulated nomadic migrations, pasture use rights, and herd species compositions (Humphrey and Sneath 1999). Communities also regulated the establishment of pasture reserves for winter use and for emergency forage during negative climatic events. Therefore, overgrazing and grassland degradation were prevented during the pre-revolutionary period through the reinforcement of traditional nomadic grazing and systematic pasture use through collective action. 
After the Inner Mongolia Autonomous Region was established by the Communist Party of China in 1947, nomadic herders in NBR were reorganized into collective herding units and livestock were seized from ruling elites and monasteries, and redistributed to pastoral households. The herding collectives provided veterinary assistance to herders as well as constructed infrastructure to facilitate seasonal migrations and milk and meat production. The collectives also continued to regulate the establishment of reserve pasture for emergency forage (Williams 2002).

In 1996, collective management of grasslands ceased after the local government of NBR decided to initiate the Grassland Contract Policy that had been instituted in most of the other regions of Inner Mongolia in the late 1970s to mid-1980s. Government officials divided up available grassland among herding families based on their hukou (household registration) status in the region as well as the number of livestock they had at the time their grassland contract was initiated. The average land holdings for survey participants was 622.5 hectares $(9,338 \mathrm{mu})(1$ hectare $=15 \mathrm{mu})$, although, some study participants had access to as little as 213 hectares $(3,200 \mathrm{mu})$ of grassland while others acquired as much as 2,000 hectares (30,000 $\mathrm{mu}$ ) through renting additional grassland from other families. When asked about the disparities between the size and quality of many families' land holdings, many herders asserted that although land was originally intended to be divided equitably among families, they felt that some families had been given preferential treatment by local officials. For example, when asked why he had been given so little land in relation to his neighbors, one forty year old herder commented angrily in Mandarin "Tamen you hao guanxi! (Translated: They had good relationships with the officials!)"

After dividing grassland among pastoral families, the banner government then established local grassland stations to monitor the quality of available grassland and to assign a fixed livestock carrying capacity to each family's pasture allocation that is recalculated every three years. In 2012, the state-assigned carrying capacity for NBR grasslands was one sheep unit per $20 \mathrm{mu}$ of grassland. However, because livestock products are one of the sole sources of income for pastoral families, many herders far exceeded their maximum allowance for livestock. Regardless of the size of their pasture allocation, age, or economic status, at the time of this study, over $90 \%$ of study participants reported herd sizes far in excess of the carrying capacity that was assigned to their land. In some cases, herders reported stocking rates greater than three times their maximum allowance (Conte and Tilt 2014). Thus, the grassland contracting policy has effectively ended NBR's traditional nomadic system of livestock management because the policy has ossified the boundaries between family pasture allocations and rendered nomadic grazing impossible (Williams 2002). Herders must now manage excessive numbers of livestock by relying solely on the grassland resources on their pasture allocations, and supplementary sources of fodder (Figure 3).

In response to sedentarization and ecologically unsustainable stocking rates, the local government and the pastoral community recognize signs of ecological degradation in NBR. Most notably, local pastoralists believe that local plant species associations are changing such that plant species that are less nutritious or dangerous to livestock are becoming more prevalent on the surrounding grasslands relative to nutritious, favorable species. For example, many herders report an overall increase in Stipa baicalensis (Roshevitz 1929), a species of needle grass with hard, pointed seeds that can injure or kill livestock (Wang 1992). Herders and local grassland monitoring personnel assert that the species has always been present in the surrounding ecology, but as constant grazing pressure is place on limited grasslands, it is beginning to dominate species associations.

Although previous research ( $\mathrm{Li}$ and Huntsinger 2011; Williams 2002) suggests that sedentarization is contributing to grassland degradation and overgrazing in Inner Mongolia, the provincial government of Inner Mongolia and the national government of China are more inclined to attribute land degradation to unsustainable stocking rates rather than the lack of flexible mobile grazing systems. For example, in response to the rise in unfavorable plant species, the NBR government initiated a policy that would require pastoral families to limit their herd size to 200 sheep units regardless of the size of their land holdings, and to increase the amount of their livestock that are exclusively stall-fed. Therefore, the government is attempting to curb land degradation in Inner Mongolia by limiting livestock numbers and increasing industrialized livestock production, rather than acknowledging the failures of sedentarization and land privatization policies. Furthermore, while the Republic of Mongolia has acknowledged the ecological importance of seasonal 
mobility and is seeking to develop land management policies designed to work in conjunction with pastoral mobility (SDC 2010), the Chinese state continues to promote sedentarization and aims to fully sedentarize nomadic communities in the Xinjiang Uighur and Tibet Autonomous Regions (Ptackova 2011; Xinhua 2012).

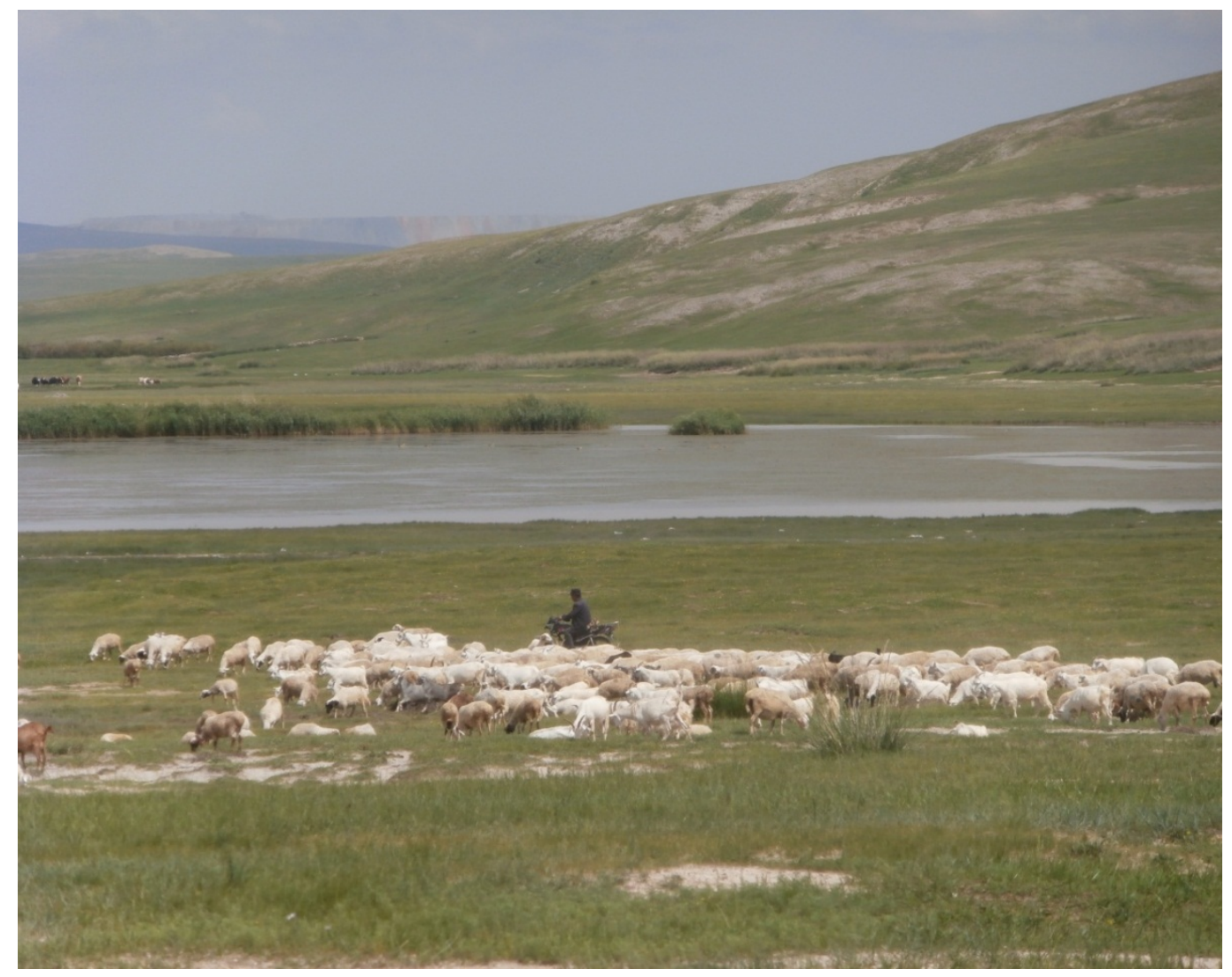

Figure 3: A Barga pastoralists herds his sheep by motorcycle. Source: author.

Although the nomadic grazing strategies practiced by NBR herders prior to 1996 have been disrupted by implementation of the Grassland Contract Policy and are currently prohibited by Inner Mongolian law, as explained above, some NBR pastoralists are able to retain a degree of seasonal mobility by renting additional pastures from other families. Many herders will attempt to make at least one migration to additional pastures each year, and some families are able to move between two and four times during the year. This strategy allows them to relieve grazing pressure on their own private grassland allocations each season. However, although this system of mobility might seem similar to the traditional nomadic system that existed in NBR prior to the mid-1990s, many herders have expressed mixed feelings regarding the usefulness of this contemporary system of mobile grazing. One 29 year old herder asserted:

I think we need to move to keep our animals and land healthy, but it's useless to move now. My family has only one pasture and it has good grass for summer but not for winter. If we rent another pasture in the winter that also only has good plants for summer, the move is useless. (in Conte and Tilt 2014).

This comment is indicative of the fact that previous forms of pastoral mobility took into account the plant species associations and topographic conditions ideal for different seasons and livestock species (Fernandez-Gimenez 2000). Thus, the new form of mobility is based more on range availability and monetary 
compensation than on the seasonal needs of livestock species. Nevertheless, the mobile segment of the NBR pastoral population still values pastoral mobility, even as other herders have chosen to remain fully sedentary. Therefore, because there is a segment of NBR pastoralists that maintains seasonal movement, mobility served as the unit of comparison in this study.

\section{Methods for measuring herder perceptions}

This research was conducted in the three case-study villages using a mixed methods approach during the summer of 2012. Semi-structured field interviews $(n=12)$ were conducted with herders and key community leaders to investigate changes in grassland management and settlement patterns since privatization, and herders' perceptions of changes in grassland health. The author also developed a scaled survey instrument ( 1 = strongly disagree, 2 = disagree, $3=$ neutral, $4=$ agree, $5=$ strongly agree) which was administered to a sample of 50 pastoral households. The survey variables addressed herders' perceptions about their ability to effectively manage grasslands, to cope with natural disasters, and to promote grassland health. Additional survey variables addressed herders' perceptions of the future economic viability of pastoralism, their desire to have their children become herders, and the future health of their local grasslands. Table 1 shows the age, ethnicity, and mobility breakdown for the sample population. Because the author lacked access to local population censuses, convenience sampling was used to recruit the sample population (Bernard 2006: 191-192).

\begin{tabular}{|cccccccccc|}
\hline \multicolumn{2}{|c}{ Ethnicity } & \multicolumn{2}{c}{ Sex } & \multicolumn{3}{c}{ Age } & \multicolumn{2}{c|}{ Settlement Pattern } \\
Han & Mongol & Male & Female & Mean & Median & Range & Sedentary & Mobile \\
9 & 41 & 33 & 17 & 39.46 & 38 & $18-67$ & 25 & 25 \\
\hline
\end{tabular}

Table 1: Description of sample population: $\mathrm{n}=50$.

The author chose a quantitative survey approach to measure pastoralists' attitudes towards their current grassland management practices and the future of pastoralism because of the short time scale of this research project, and difficulties in conducting social science research in NBR due to the political climate of China's frontier regions. NBR's position on two of China's international borders makes many areas of the Banner restricted for foreign researchers, and the movement of foreign nationals is heavily regulated and monitored by local police and the People's Liberation Army. Therefore, the survey approach enabled the author to collect data quickly and employ a deductive approach to statistically compare the attitudes of each settlement category and to test the study hypotheses. Additionally, the survey variables utilized allow for the possibility of future comparisons across sites. Table 2 illustrates the mean responses and standard deviations for survey variables pertaining to rangeland management and the future of pastoralism in NBR.

The author then divided the sample population into two categories based on pastoral mobility. Herders that reported no pastoral movements in the previous twelve months were classified as 'sedentary', and those that reported at least one pastoral migration in that time were classified as 'mobile.' Therefore, the analysis included herders that maintain seasonal movement and those that have become fully sedentary as a result of the Grassland Contract Policy.

In order to test for both within and between-group agreement on the survey variables, the author employed inter-rater reliability using Cronbach's Alpha (Atran et al. 2007; Bang et al. 2007). This analysis measures inter-rater agreement on a zero to one scale in which a measure of zero indicates perfect disagreement among raters and one indicates perfect agreement. Using this analysis, the author aimed to test whether herders representing different settlement patterns share the same attitudes regarding the effectiveness of their current grassland management practices and the future of pastoralism in NBR, or if sedentarization 
and the privatization of grassland have led them to represent distinct populations within the same pastoral community.

To test the first hypothesis, that herders who retain mobility would have a more positive attitude toward the perceived effectiveness of their current grassland management practices and the future of pastoralism, the author used Mann-Whitney U Tests (a commonly used non-parametric procedure) to observe whether or not there was a statistically significant difference between the responses of each settlement category to the survey variables. Mann-Whitney U Tests differ from independent samples t-tests in that they compare the mean-ranks between two study populations rather than mean responses. Therefore, this test is more appropriate for analyzing non-normally distributed data.

Because this research was conducted by a foreign researcher in a politically sensitive area of China, it is also important to reflect on the local government and study population's perceptions of the author and research team. First, during the data collection process, the author was required to report his research goals and academic credentials to local police authorities. This is due to the fact that NBR is frequently used as a pathway by refugees fleeing from the DPRK into the Republic of Mongolia. Furthermore, because the author was one of the first United States citizens to conduct research in NBR, local pastoralists were initially suspicious of the author and reluctant to participate in surveys. However, following the assurance of confidentiality and being given an opportunity to ask questions regarding the nature of the research project, they were more receptive to answering the survey instrument. It is also helpful to note the limitations of utilizing a survey instrument designed prior to arriving at the field site. For example, upon initially viewing the survey instrument, some herders commented that they could not answer a survey variable pertaining to conducting otor and emergency migrations because these were nearly impossible to do in the current system regardless if herders were able to move to rented pastures during the year. Therefore, this survey variable was altered to reflect this fact. Thus, the author relied on ethnographic interviews and qualitative data to validate and modify survey variables.

\section{Resulting data and analysis}

Table 2 provides study participants' mean responses and standard deviations for the survey variables pertaining to their current grassland management practices and the future of pastoralism as a viable economic activity in NBR. Overall mean responses indicate general agreement that forage quality will increase and that pastoralism will remain a viable livelihood in NBR in the future. However, study participants of each settlement category generally disagreed that they could make effective management decisions to provide their livestock with forage and water during natural disasters such as white and black dzud. Herders of each settlement category also generally agreed that they would be able to continue managing their family's pasture allocation in the future without fear of frequently changing land tenure laws.

To test the first hypothesis that pastoralists representing sedentary and mobile settlement patterns would not share the same attitudes towards the effectiveness of their grassland management strategies and the future viability of pastoralism in NBR, the author conducted inter-rater reliability analysis to assess the level of agreement in survey responses both between and within each settlement category. Tables 3 and 4 illustrate the results of this analysis for survey variables pertaining to grassland management practices and the future of pastoralism in the region. 


\begin{tabular}{|c|c|c|c|}
\hline Variable & $\begin{array}{l}\text { Sedentary } \\
\text { (Mean, St. } \\
\text { Deviation) }\end{array}$ & $\begin{array}{l}\text { Mobile } \\
\text { (Mean, St. } \\
\text { Deviation) }\end{array}$ & $\begin{array}{c}\text { Total } \\
\text { (Mean, St. } \\
\text { Deviation) }\end{array}$ \\
\hline $\begin{array}{l}\text { 1.During times of drought, I can move my } \\
\text { livestock to new pastures if I need to. }\end{array}$ & $3.16(1.80)$ & $4.12(1.36)$ & 3.64 (1.65) \\
\hline $\begin{array}{l}\text { 2. During a white disaster, I can take my } \\
\text { livestock to where they can get enough } \\
\text { forage to eat. }\end{array}$ & $2.24(1.51)$ & $2.04(1.72)$ & $2.14(1.60)$ \\
\hline $\begin{array}{l}\text { 3. During a black disaster, I can take my } \\
\text { livestock to where they can get enough } \\
\text { water to drink. }\end{array}$ & $1.96(1.46)$ & $2.88(1.74)$ & $2.42(1.65)$ \\
\hline $\begin{array}{l}\text { 4. Herd mobility is needed to manage } \\
\text { grasslands effectively }\end{array}$ & 3.96 (1.59) & 4.44 (1.16) & $4.20(1.40)$ \\
\hline $\begin{array}{l}\text { 5. The way herders herd their animals } \\
\text { now gives grassland enough time to } \\
\text { regenerate before it is grazed again. }\end{array}$ & $3.68(1.41)$ & $4.04(1.10)$ & $3.86(1.26)$ \\
\hline $\begin{array}{l}\text { 6. Fencing pastures helps herders to } \\
\text { manage grassland more effectively than } \\
\text { before grassland was contracted to } \\
\text { individual families. }\end{array}$ & 3.72 (1.59) & $3.68(1.46)$ & $3.70(1.51)$ \\
\hline $\begin{array}{l}\text { 7. I have a harder time conducting } \\
\text { seasonal movements now than in the past. }\end{array}$ & $3.44(1.71)$ & $2.96(1.88)$ & $3.20(1.86)$ \\
\hline $\begin{array}{l}\text { 8. In the future, grassland health will } \\
\text { decrease. }\end{array}$ & $2.60(1.44)$ & $2.76(1.42)$ & $2.68(1.42)$ \\
\hline $\begin{array}{l}\text { 9. In the future, herders will be able to } \\
\text { make a good living from livestock } \\
\text { herding }\end{array}$ & $4.28(1.31)$ & $4.24(1.16)$ & $4.26(1.23)$ \\
\hline $\begin{array}{l}\text { 10. I feel that livestock herding is a good } \\
\text { occupation for my children. }\end{array}$ & $1.80(1.44)$ & 2.32 (1.49) & $2.06(1.48)$ \\
\hline $\begin{array}{l}\text { 11. The quality of forage in my area will } \\
\text { increase in the future. }\end{array}$ & 3.64 (1.47) & $4.08(1.32)$ & $3.86(1.40)$ \\
\hline $\begin{array}{l}\text { 12. I am confident that I will be able to } \\
\text { manage the same land I am managing } \\
\text { now } 20 \text { years in the future. }\end{array}$ & $4.40(1.22)$ & $4.44(1.00)$ & $4.42(1.11)$ \\
\hline $\begin{array}{l}\text { 13. Because laws change so frequently, I } \\
\text { am worried that I will not be able to use } \\
\text { the land I am using now in the future. }\end{array}$ & $2.40(1.76)$ & $2.60(1.85)$ & 2.50 (1.79) \\
\hline
\end{tabular}

Table 2: Mean Responses for grassland management and future of pastoralism survey variables ${ }^{1}{ }^{1}$ Variables coded on a 5 -point scale ( $1=$ strongly disagree, $5=$ strongly agree). 


\begin{tabular}{|lcc|}
\hline Settlement Type & Sample Size & Cronbach's Alpha $(\alpha)$ \\
Sedentary $^{1}$ & 25 & .81 \\
Mobile $^{2}$ & 25 & .88 \\
Between Groups & 50 & .92 \\
\hline
\end{tabular}

${ }^{1}$ Herders who reported 0 pastoral movements during the previous 12 months

${ }^{2}$ Herders who reported at least 1 pastoral movement during the previous 12 months

Table 3: Intra/Inter-group agreement for grassland management variables.

Inter-rater reliability analysis for attitudes towards current grassland management practices and settlement patterns indicate a high level of intra-group agreement for both the sedentary $(\alpha=.81)$ and mobile $(\alpha=.88)$ settlement categories. There was also a high level of inter-group agreement between the sedentary and mobile categories of the sample population $(\alpha=.92)$. Inter-rater reliability analysis for the survey variables pertaining to attitudes towards the future of pastoralism in NBR also indicate a high level of both intra-group agreement for the sedentary $(\alpha=.91)$ and mobile $(\alpha=.92)$ settlement categories and a high degree of inter-group agreement $(\alpha=.96)$ between each settlement category. Therefore, the results of this analysis show high levels of agreement on the survey variables between the sedentary and mobile categories of the study population, indicating that study participants of each settlement category consistently agree in their responses to the survey instrument.

\begin{tabular}{|c|c|c|}
\hline Settlement Type & $\underline{\text { Sample Size }}$ & Cronbach's Alpha $(\alpha)$ \\
\hline Sedentary ${ }^{1}$ & 25 & .91 \\
\hline Mobile $^{2}$ & 25 & .92 \\
\hline Between Groups & 50 & .96 \\
\hline
\end{tabular}

${ }^{1}$ Herders who reported 0 pastoral movements during the previous 12 months

${ }^{2}$ Herders who reported at least 1 pastoral movement during the previous 12 months

Table 4: Intra/Inter-group agreement for future of pastoralism variables.

To test the second hypothesis that mobile herders would have more positive attitudes both towards their current grassland management practices and the future of pastoralism, the author conducted MannWhitney U Tests for the thirteen variables pertaining to grassland management practices and the future of pastoralism. The results of this analysis are shown in Table 5.

The results of the Mann-Whitney U Tests indicate that there are few statistically significant differences in the responses to these survey variables (at the 95\% confidence level) between the sedentary and mobile segments of the sample population. The only exception is the variable "During a black disaster, I can take my livestock to where they can get enough water to drink" $(z=2.24, p=.03)$. For this variable, the mobile segment of the study population has a significantly more positive attitude towards their perceived ability to cope with the effects of a black disaster and avoid livestock loss than the sedentary segment of the population. 


\begin{tabular}{|c|c|c|c|c|}
\hline Variable & $\underline{z \text {-value }}$ & $p$ - value & $\frac{\underline{\text { Sedentary Mean }}}{\underline{\text { Rank }^{1}}}$ & $\frac{\text { Mobile Mean }}{\underline{\text { Rank }}}$ \\
\hline $\begin{array}{l}\text { 1. During times of drought, I can } \\
\text { move my livestock to new pastures if } \\
\text { I need to. }\end{array}$ & 1.91 & .06 & 21.8 & 29.1 \\
\hline $\begin{array}{l}\text { 2. During a white disaster, I can take } \\
\text { my livestock to where they can get } \\
\text { enough forage to eat. }\end{array}$ & -.64 & .52 & 26.7 & 24.3 \\
\hline $\begin{array}{l}\text { 3. During a black disaster, I can take } \\
\text { my livestock to where they can get } \\
\text { enough water to drink. }\end{array}$ & 2.24 & $.03 *$ & 21.2 & 29.8 \\
\hline $\begin{array}{l}\text { 4. Herd mobility is needed to manage } \\
\text { grasslands effectively }\end{array}$ & 1.04 & .30 & 23.7 & 27.3 \\
\hline $\begin{array}{l}5 \text {. The way herders herd their animals } \\
\text { now gives grassland enough time to } \\
\text { regenerate before it is grazed again. }\end{array}$ & .78 & .44 & 24 & 27 \\
\hline $\begin{array}{l}\text { 6. Fencing pastures helps herders to } \\
\text { manage grassland more effectively } \\
\text { than before grassland was contracted } \\
\text { to individual families. }\end{array}$ & -.20 & .85 & 25.9 & 24.3 \\
\hline $\begin{array}{l}\text { 7. I have a harder time conducting } \\
\text { seasonal migrations now than in the } \\
\text { past. }\end{array}$ & -.64 & .52 & 26.7 & 24.3 \\
\hline $\begin{array}{l}\text { 8. In the future, grassland health will } \\
\text { decrease. }\end{array}$ & .38 & .70 & 24.7 & 26.3 \\
\hline $\begin{array}{l}\text { 9. In the future, herders will be able to } \\
\text { make a good living from livestock } \\
\text { herding }\end{array}$ & -.58 & .57 & 26.5 & 24.5 \\
\hline $\begin{array}{l}\text { 10. I feel that livestock herding is a } \\
\text { good occupation for my children. }\end{array}$ & 1.48 & .14 & 22.8 & 28.2 \\
\hline $\begin{array}{l}\text { 11. The quality of forage in my area } \\
\text { will increase in the future. }\end{array}$ & 1.10 & .28 & 23.5 & 27.5 \\
\hline $\begin{array}{l}\text { 12. I am confident that I will be able } \\
\text { to manage the same land I am } \\
\text { managing now } 20 \text { years in the future. }\end{array}$ & -.38 & .70 & 26.1 & 24.9 \\
\hline $\begin{array}{l}\text { 13. Because laws change so } \\
\text { frequently, I am worried that I will } \\
\text { not be able to use the land I am using } \\
\text { now in the future. }\end{array}$ & .41 & .68 & 24.7 & 26.3 \\
\hline
\end{tabular}

*Statistically significant comparison

${ }^{1}$ Mean rank refers to the number of high or low scores reported in a given group. Hence, the group with the highest mean rank has reported the higher number of high scores relative to the low group.

Table 5: Comparison of attitudes towards grassland management and future of pastoralism between settlement categories. 
The author then conducted a power analysis to test if the study was sufficiently powered to detect statistically significant differences in responses to the twelve statistically insignificant Mann-Whitney U Tests if they were present. This analysis was performed using the mean responses and standard deviations of sedentary and mobile herders to determine the effect size (Cohen's $d$ ) between the sample distributions for each of the thirteen statistically insignificant comparisons. The results of power analysis indicated that this study was not sufficiently powered to detect a statistically significant difference between the sedentary and mobile segments of the study population, at the small and medium effect sizes observed for each of the twelve statistically insignificant Mann-Whitney U Tests. Thus, the statistical comparisons the author used to analyze the survey data require larger sample sizes to be definitive.

\section{Discussion}

This study's lack of statistical power is due to the limits on sample size given the short time-frame of this research, and the author's limited access to pastoral populations in NBR. In addition, previous research suggests that there should be a large effect size between herders that maintain a grazing system more closely related to the traditional nomadic land management system and those that follow a non-indigenous sedentary system (Williams 2002). Therefore, the research was designed to detect a large effect between settlement categories. Although the Mann-Whitney U Tests were not sufficiently powered to conclusively show that there is a statistically significant difference between the survey responses of each settlement category, the high levels of agreement yielded by the inter-rater reliability analysis suggests that the same insignificant results would be observed if sufficient samples sizes were attained.

The high levels of agreement indicated by the results of the inter-rater reliability analysis lead the author to reject the hypothesis that herders representing different settlement patterns would not share the same attitudes towards the survey variables pertaining to grassland management and the future of pastoralism in NBR. These findings could be a result of a homogenizing effect on herder attitudes due to current policy that is leading them to share the same attitudes towards grassland management and the future economic viability of pastoralism, regardless of their different settlement patterns. The high levels of agreement and statistically insignificant differences in responses to the survey variables could be due to the fact that the system of movement practiced by the mobile segment of the sample population differs greatly from the traditional nomadic system of herding practiced in NBR prior to 1996. Therefore, although they are able to retain some seasonal mobility, the mobile segment of the study population has also been affected by policies that have led herders to adopt non-indigenous land management practices. However, the significantly more positive attitudes of mobile herders on the survey variable pertaining to effective livestock management during black disasters could be a result of the mobile segment of the population's ability to conduct seasonal pastoral movements to pastures that have different water and plant-species conditions.

The quantitative and qualitative data collected during this study indicate that privatization and sedentarization policies are affecting herders of both settlement categories in several ways. First, sedentary and mobile herders indicated in both their mean responses to the survey variable "herd mobility is needed to maintain healthy grasslands" (3.96, 4.44, respectively) and during interviews that they value pastoral mobility and believe that it contributes to healthy livestock and to productive grassland. One forty-year-old male herder commented "If you stay in one place all the time, the animals trample the ground and the grass can't grow well. If you move each season, the animals trample the ground for a short amount of time and then the land can rest." However, although herders value mobility, the mean responses to the survey variable "fencing grasslands helps herders manage grasslands more effectively than before grassland was contracted to individual families" of both sedentary and mobile herders (3.72, 3.68, respectively) indicate that study participants feel a moderate degree of agreement that the fencing policy that led to the collapse of the nomadic system also helps them to effectively manage their land. Therefore, fencing may be becoming engrained in the local perceptions of effective grassland management because herders no longer have the ability to move freely within NBR grasslands. Thus, regardless of the pastoral populations' belief that mobility is valuable, they may believe that fencing is an effective means of resting pastures following grazing. And so, fencing could be changing the traditional land use ethics and common-pool resource management strategies in NBR such that 
herders now value a privatized system that they acknowledge is restricting their ability to be mobile (Conte and Tilt 2014; Williams 2002).

Both herders and local grassland researchers agree that grassland quality and plant species biodiversity have decreased since 1996. For example, when asked about changes in grassland conditions since 1996, one interview participant commented that "the plant species that are bad for the animals have always been present here. But, since 1996, the bad species are becoming more and more common and the animals are less healthy because of it." One local grassland researcher commented: "prior to privatization in the mid-1990s, grassland ecologists would typically observe over twenty plant species in their annual test plots in this area. Nowadays we only see seven to ten, and there has been a decline in the species that the animals, especially sheep, like to eat." These statements are consistent with previous research in Inner Mongolia that suggests one of the key indicators of grassland degradation and overgrazing is an overall decline in plant species biodiversity and plant species favorable for livestock consumption (Humphrey and Sneath 1996a).

Regardless of their perceptions of the indicators of overgrazing and land degradation, herders from both settlement categories agreed that their grassland management practices are effective and that they are optimistic that the health of NBR grasslands would increase in the future. When asked why they felt this, even though they also acknowledged a decrease in grassland health since privatization, many survey and interview participants cited favorable precipitation and weather conditions in the previous twelve months. One interview participant emphatically asserted "This year's rain was very good, so I think the grass will get better and better." After responding to survey variables pertaining to the future of grassland health in NBR, many survey respondents stated "It all depends on rain and weather." These findings are consistent with those of Fernandez-Gimenez (2000), who found that pastoralists in central Mongolia viewed weather and climatic conditions as having more influence on grassland health than livestock management decisions. Because annual precipitation conditions in northeastern Inner Mongolia vary greatly, NBR herders may not recognize the long-term consequences of current land use policy and livestock management practices (FernandezGimenez 2000). This could be due in part to increasingly erratic precipitation conditions in Inner Asia as a result of climate change. Furthermore, because traditional ecological knowledge is formed generationally through the accumulation of experiential knowledge, the current unprecedented pace of ecological change could be rendering the traditional ecological knowledge of Mongolian herders less effective in helping them make land management decisions (Berkes 1999).

Previous political ecology research in Inner Mongolia (i.e. Jiang 2004; Williams 2002) has emphasized the significance of government policy in contributing to land degradation and a decline in economic livelihoods among Inner Mongolian pastoralists. However, climatologists suggest that Inner Mongolian grasslands are extremely vulnerable to anthropogenic climate change and are in decline due to a complex combination of socioeconomic and ecological drivers (Dai et al. 2009; Xiao et al. 1995). Most notably, climatological data indicates that mean annual temperatures throughout Inner Mongolia are increasing while mean annual precipitation is decreasing (Liu and Wang 2012). Therefore, this indicates that land degradation in Inner Mongolia may be the result of a combination of sociopolitical and ecological drivers that are each contributing to the destruction of naturally occurring grasslands and the cultural and economic survival of the pastoralists that depend on the grasslands.

Land tenure issues and policy changes have also been a key area of concern in previous research on Inner Mongolian pastoralists' land management and economic decision making. Williams (2002) found that frequent changes to land tenure laws in the 1980s-1990s had negatively affected pastoralists' ability and willingness to make long-term land management decisions because they were unsure of the amount of years they would have access to their pasture allocation. When asked if they were concerned about their ability to manage their land in the future, many survey and interview respondents indicated that they were not concerned that they would lose the right to use their land before their standard 30 year contract had expired. In addition, many herders indicated that they expected to be able to use their family's grassland for fifty years or more. Therefore, the data suggests that NBR pastoralists may be becoming more confident in current land tenure laws which have stabilized since the late 1990s throughout rural China (Li et al 1998). 


\section{Conclusions}

This study suggests two possible conclusions regarding the effects of state policies that have altered indigenous land management and economic production systems in Inner Mongolia. First, marketization and privatization could be destroying the Mongolian land management system, such that the privatization of grassland and sedentarization of nomadic herders is contributing to grassland degradation and eroding the traditional Mongolian land values that enabled herders to sustainably manage grasslands in the past. Hence, although herders recognize that grassland health is decreasing, they have adapted their economic behavior in such a way that they now value the non-indigenous system of livestock production that was initiated in NBR two decades ago. In this case, NBR pastoralists are presented with two potential settlement strategies (either becoming fully sedentary or remaining mobile by renting additional pastures), neither of which is likely to promote sustainable livelihoods in the future. The sedentary strategy presents herders with the challenge of grazing large numbers of animals on limited land year-round, and depending on the availability of supplementary fodder to sustain their herds during the winter. The mobile strategy, while presenting herders with the opportunity to access additional pasture, also leaves herders at the mercy of the availability of land for rent and the inability to conduct flexible seasonal migrations and otor during years with poor precipitation or negative climatic events. When coupled with the effects of climate change, neither of these two responses to the Grassland Contract Policy afford herders the flexibility and mobility required to effectively manage livestock on the climatologically unpredictable Inner Asian grasslands. Therefore, the Grassland Contract Policy may affect the economic livelihoods of the sedentary and mobile segments of the NBR pastoral population equally negatively.

As sedentarization and land privatization policies continue in NBR, and as annual precipitation continues to remain erratic and unpredictable, it is very likely that the negative effects of the Grassland Contract Policy and climate change will be born unevenly by members of the pastoral community, such that certain members of the community benefit or suffer more than others. In particular, herders who were given access to poor quality pasture may suffer more livestock loss or slower economic growth than those who received higher quality land in 1996. Currently, many herders who lost their livestock in natural disasters or economic downturns seek waged labor as pastoral laborers for families with larger herds. For example, one 58 year old herder commented that "herding is a new occupation here," indicating that whereas pastoralism was a cultural way of life in NBR in the past, it is now becoming a source of economic differentiation as wealthy herders 'own' their herds and less wealthy families serve as their paid employees. Therefore, sedentarization and privatization policies may be contributing to economic and social inequality in NBR and may force many traditionally pastoral families to abandon livestock herding in the future.

Another possible conclusion regarding the effects of changes in land management and settlement patterns in NBR could be the existence of a previously unknown cultural buffering effect that is leading herders of both settlement categories to share the same attitudes towards their grassland management practices and the future of pastoralism, regardless of their differing management strategies. For example, the NBR community may retain traditional Mongolian land values and environmental ethics even though the current livestock management system has rendered them impractical. Therefore, the high degree of agreement between each settlement category on the survey variables could indicate that both sedentary and mobile herders retain the same attitudinal dispositions towards their grassland management practices even as they diverge in their land management practices.

These possible conclusions regarding the effects of privatization and marketization on the attitudes of Inner Mongolian pastoralists towards land management and the future viability of pastoralism could be further analyzed in the following ways. First, since the system of mobility currently practiced in NBR by the mobile segment of the study population is far removed from the traditional nomadic system practiced before 1996, political ecologists could better study the effects of privatization policies on herder attitudes by comparing the attitudes of sedentary Inner Mongolian Barga Mongols with nomadic Barga herders living in neighboring provinces of the Republic of Mongolia. To better compare the effects of current land management strategies in NBR with that of truly nomadic herders, future research should aim to quantitatively analyze the differences in the ecological health between privatized grasslands in NBR and those across the Mongolian border that are still managed collectively. Therefore, in this way, mobility based on 
traditional ecological knowledge and common-pool resource management, rather than pastoral mobility adapted to a sedentary system, can serve as the unit of both cultural and ecological comparison in future studies.

Finally, in the future, political ecologists specializing in Inner Mongolia should seek to combine ecology and policy research so as to paint a clearer picture of the nexus between ecological degradation, climate change, and state policy and their contribution to the environmental and sociopolitical issues that pastoral communities face (Charnley and Durham 2010). In this way, future researchers can use ecological and climatological data to effectively assess the effects of policy decisions and to validate study participants' perceptions of ecological change. Hence, future researchers could not only provide valuable insights on how current Inner Mongolian grassland management policy may contribute to ecological degradation, but also how it may serve to increase the economic vulnerability of the pastoral communities who are bearing the effects of a rigid sedentary system in a landscape that requires flexibility and mobility. Future assessments of the effects of Chinese grassland policy require a political ecology that provides equal focus on both the political and ecological challenges that Chinese pastoralists face.

\section{References}

Atran, S., Ross, N.O., Medin, D. L. 2005. The cultural mind: environmental decision making and cultural modeling within and across populations. Psychological Review 112: 744-776.

Bang, M., Medin, D.L., Atran, S. 2007. Cultural mosaics and mental models of nature Proceedings of the National Academy of Sciences 104(35) 13868-13874.

Banks, T., Doman, S. 2001. Kazakh nomads: grassland policy and the environment in Altay: insights from new range ecology. Presented at the Second International of Asia Scholars. Free University, Berlin, 12 August 2001.

Berkes, F. 1999. Sacred ecology: traditional ecological knowledge and resource management. Anne Arbor, MI: Taylor and Francis.

Bernard, H. R. 2006. Research methods in anthropology: qualitative and quantitative approaches. New York: Altimira Press. Pp 144-147.

Begzsuren, S., Ellis, J.E., Ojima, D.S., Coughenour, M.B., Chuluun, T. 2004. Livestock responses to droughts and severe winter weather in the Gobi Three Beauty National Park, Mongolia. Journal of Arid Environments 59(4): 785-796.

Charnley, S., Durham, W.H. 2010. Anthropology and environmental policy: what counts? American Anthropologist 112(3): 397-415.

Conte, T.J. and Tilt, B. 2014. The effects of China's grassland contract policy on pastoralist attitudes towards cooperation in an Inner Mongolian banner. Human Ecology 42: 837-846. draft

Dai, X., Xu, Y., Jia, G., Fu, C. 2009. Climate change impact and adaptation in Inner Mongolia. IOP Conference Series: Earth and Environmental Science 6, session 34.

Daly, C., Hannaway, D.B. 2005. China atlas: visualizing China's future agriculture: climate, soil, and suitability maps for improved decision making. Corvallis, OR: Oregon State University.

Deng, X., Huang, J., Huang, Q., Rozelle, S., Gibson, J. 2009. Do roads lead to grassland degradation or restoration? A case study in Inner Mongolia, China. Environment and Development Economics 16(6): 751-773.

Dove, M.R. 1995. Rice-eating rubber and people-eating governments: peasant versus state critiques of rubber development in colonial Borneo. Ethnohistory 43(1): 33-63.

Dove, M.R. 1986. The practical reason of weeds in Indonesia: peasant vs. state views of Imperata and Chromolaena. Human Ecology 14(2): 163-190.

Ericksen, A. 2013. Negotiating winter migrations in Mongolia: results not guaranteed. Society for Applied Anthropology conference, Denver, CO, USA. 
Fernandez-Gimenez, M. E., Le Febre, S. 2006. Mobility in pastoral systems: dynamic flux or downward trend? International Journal of Sustainable Development and World Ecology 13(5):341-362.

Fernandez-Gimenez, M.E. 2000. The role of Mongolian nomadic pastoralists' ecological knowledge in grassland management. Ecological Applications 10(5): 1318-1326.

Fernandez-Gimenez, M.E., Allen-Diaz, B. 1999. Testing a non-equilibrium model of grassland vegetation dynamics in Mongolia. Journal of Applied Ecology 36(6): 871-885.

Fratkin, E. 1997. Pastoralism: governance and development issues. Annual Review of Anthropology. 26: 236261.

Hardin, G. 1968. The tragedy of the commons. Science 162: 1243-1248.

Ho, P. 1996. Ownership and control in Chinese grassland management since Mao: The case of free-riding in Ningxia. Pastoral Development Network Series 39. London: Overseas Development Institute.

Holmes, F. 2012. China's next act. Retrieved from: http://www.advisorperspectives.com/commentaries/global_0090712.php

Hu, S.T., Hannaway, D., Youngberg H. 1992. Forage resources of China. Wageningen, Netherlands: Centre for Agricultural Publishing and Documentation (PUDOC).

Humphrey, C., Sneath, D. 1999. The end of nomadism? Society, state, and the environment in Inner Asia. Cambridge, UK: The White Horse Press.

Humphrey, C., Sneath, D. 1996a. Culture and environment in Inner Asia 1: The pastoral economy and the environment. Cambridge, UK: The White Horse Press.

Humphrey, C., Sneath, D. 1996b. Culture and environment in Inner Asia 2: society and culture. Cambridge, UK: The White Horse Press.

Jiang, H. 2004. Grassland management and views of nature in China since 1949: regional policies and local changes in Uxin Ju, Inner Mongolia. Geoforum 36: 641-653.

Lattimore, O. 1940. Inner Asian frontiers of China. New York: American Geographic Society.

Li, G., Rozelle, S., Brandt, L. 1998. Tenure, land rights, and farmer investment incentives in China. Agricultural Economics 19: 63-71.

Li,W., Hunsinger, L. 2011. China's grassland contract policy and its impacts on herder ability to benefit in Inner Mongolia: tragic feedbacks. Ecology and Society 16(2).

Liu, B. n.d. Map of New Barag Right Banner.

Liu, S., Wang, T. 2012. Climate change and local adaptation strategies in the middle Inner Mongolia, northern China. Environmental Earth Sciences 66(5): 1449-1458.

Ma, R. 2003. Changes in local administration and their Impact on community life in the grasslands of Inner Mongolia, China. China Report 39(4): 459-475.

McCabe, T. 2004. Cattle bring us to our enemies: Turkana ecology, politics, and raiding in a disequilibrium system. Ann Arbor, MI: University of Michigan Press.

Nelson, R. 2006. Regulating grassland degradation in China: shallow-rooted laws? Asian-Pacific Law and Policy Journal 7(2): 385-417.

Pasternak, B., Salaff, J. 1993. Cowboys and cultivators: the Chinese of Inner Mongolia. Boulder, CO: Westview Press.

Ptackova, J. 2011. Sedentarization of Tibetan nomads in China: implementation of the nomadic settlement project in the Tibetan Amdo area: Qinghai and Sichuan provinces. Pastoralism: Research, Policy and Practice 1(4).

Roshevitz, I. 1929. Flora of China 26: 196, 198. Retrieved from: http://www.efloras.org/florataxon.aspx?flora_id=2andtaxon_id=200026367

Rozelle, S., Brandt, L., Li. G., Huang J. 2005. Land tenure in China: facts, fictions, and issues. In Peter Ho (ed.) Developmental dilemmas: land reform and institutional change in China. New York: Routledge. Pp. 121-150. 
Sawyer, J. 2010. Mongolian dzud kills millions of livestock. National Geographic. Retrieved from: http://newswatch.nationalgeographic.com/2010/04/26/mongolian_dzud_kills_millions/

SDC (2010) A livelihood study of herders in Mongolia. Geneva: Swiss Agency for Development and Cooperation.

Sheehy, D.P. 1993. Grazing management strategies as a factor influencing ecological stability of Mongolian grasslands. Nomadic Peoples 33: 17-30.

Taylor, J.L. 2012. Constraints of grassland science, pastoral management and policy in northern China: anthropological perspectives on degradational narratives. International Journal of Development Issues 11(3): 208-226.

Taylor, J.L. 2006. Negotiating the grassland: the policy of pasture enclosures and contested resource use in Inner Mongolia. Human Organization 65(4): 374-386.

Tilt, B. 2008. Smallholders and the 'household responsibility system': adapting to institutional change in Chinese agriculture. Human Ecology 36(2): 189-199.

UNDP. 2010. UNDP On early recovery: 2009-2010 Mongolian dzud. Retrieved from: http://www.undp.mn/publications/Early_recovery.pdf

Wang, Y. 1992. Vegetation dynamics of grazing succession in the Stipa baicalensis steppe in Northeastern China. Vegetation 98(1): 83-95.

Williams, D.M. 2002. Beyond great walls: environment, identity, and development on the Chinese grasslands of Inner Mongolia. Stanford, CA: Stanford University Press.

Williams, D.M. 1996. Grassland enclosures: catalyst of land degradation in Inner Mongolia. Human Organization 55(3): 307-313.

Xiao, X., Ojima, D.S., Patron, W.J., Chen, Z., and D. Chen. 1995. Sensitivity of Inner Mongolia grasslands to climate change. Journal of Biogeography 22: 643-648.

Xinhua. 2012. Xinjiang to hand out more subsidies to settle nomads. Retrieved from: http://www.chinadaily.com.cn/business/2012-03/15/content_14840248.htm

Zukosky, M.L. 2008. Reconsidering governmental effects of grassland science and policy in China. Journal of Political Ecology 15: 44-60. 